\title{
EFFICIENCY OF THE REGIONAL ORGANISATION OF ADVISORY CENTRES FOR CONSUMER PROTECTION IN THE REPUBLIC OF CROATIA
}

\author{
Josip Miletić ${ }^{14}$ \& Jurica Bosna ${ }^{15}$
}

UDC / UDK: 347.451.031(497.5)

JEL classification / JEL klasifikacija: K00

DOI: https://doi.org/10.22598/pi-be/2019.13.2.155

Scientific review / Pregledni znanstveni rad

Received / Primljeno: September 19, 2019 / 19. rujna 2019.

Accepted for publishing / Prihvaćeno za tisak: October 21, 2019 / 21. listopada 2019.

\section{Summary}

The paper analyses efficiency and sustainability of the recent regional organisation of the Advisory Centres for Consumer Protection in the Republic of Croatia in the context of justification of elimination thereof done by the Ministry of Economy, Entrepreneurship and Crafts. The paper includes a field research conducted among the active associations for consumer protection in the Republic of Croatia. The aim is to determine the capability of the past regional network of the consumer protection advisory centres to meet the needs of the most significant economic segment - the population of the Republic of Croatia, that is the consumers - natural persons, as the precondition for equal market competition with business entities. The paper offers an analysis of financial package of national, regional and local level of the system for consumer protection in the Republic of Croatia. The results show the inadequate efficiency and unsustainability of the recent system and offer alternative solutions in order to satisfy efficiently the needs of

\footnotetext{
${ }^{14}$ Josip Miletić, PhD, Assistant Professor, Department of Croatian and Slavic Studies, University of Zadar, E-mail: jmiletic@unizd.hr

${ }^{15}$ Jurica Bosna, PhD, Research Assistant, Department of Economics, University of Zadar, E-mail: jbosna@unizd.hr
} 
population of each Croatian region respectively and of the whole population of the Republic of Croatia.

Keywords: consumers, regional organization, consumer rights protection, consumer rights protection advisory centres.

\section{INTRODUCTION}

Consumer is any natural person who for personal purposes obtains goods or services on the market (Baretić, 2015, 7). The majority of consumers are not able to resist sophisticated marketing techniques created to influence the change in their behaviour and decision-making in buying, which they are exposed to on a daily basis (Dunković, 2016, 9). Consumers in many parts of the world are not familiar with their rights. Many of them have never even seen the key documents regulating this issue. They do not follow the recent changes to the legal regulations, and often sign contracts involving years-long obligations without a prior detailed study of the content (Jagnjić, 2017, 1). A consumer as a person who acts privately for himself/herself outside his/her economic or professional activity concludes a consumer contract with a trader as a seller acting within his economic or professional activity (Klarić P., Vedriš M., 2009, 417). Banks, insurance companies, phone operators and others often offer standard forms of contract and general business conditions (Mintas Hodak, 2010, 404) including hidden "traps", mostly written in lower case letters. Therefore, it is not surprising that the most of the US Consumer Protection Code (15 U. S. Code, Chapter 41 of The Consumer Credit Protection Act) is dedicated to consumer protection in borrowing relationships with banks and other financial institutions (Taboroši, 2006, 330). In order to minimize the potential harm, education about consumers' rights and obligations is necessary as there is not a single person who will not take on the role of a consumer in a particular situation, and often also the role of a trader (Jagnjić, 2017, 1). Implementing the consumer protection policy is the legitimate goal and task of the state as the carrier of social integration in the modern world, and not the expression of partial gains of one group against other, as sometimes it can be interpreted (Taboroši, 2006, 328-329).

Baretić $(2015,7)$ states that when it comes to consumer protection it is necessary to distinguish consumer protection policy, which implies a broader range of measures to promote and protect consumers' benefits, from consumer protection right, which consists of legal regulations. Therefore, consumer protection policy is a broader generic term that includes consumer protection right, as well as the following consumer protection policy measures: 1 . informing consumers about the properties and prices of goods; 2 . educating consumers about their rights and obligations; 3. promoting and supporting consumer 
organization so that they can protect consumer rights; 4. enabling consumer representatives participation in the activities by bodies deciding on consumer rights and obligations (Baretić, 2015, 7).

Kesić $(2006,4)$ believes that due to the digital revolution the consumer today has more power than ever before. Contemporary technology, especially the Internet, provides access to information enabling an insight into alternative products, prices, bidders, delivery terms and the like. Yet, a large number of those taking on the role of a consumer still feel uninformed (Dunković, 2016, 31). Modern democratic states constantly develop a system of consumer protection, i.e. natural persons as economically weaker parties in business transactions in the market of products and services (Odabrane, $2004,19)$. The consumer protection right is developed from civil compulsory law (Klarić P., Vedriš M., 2009, 8), and it consists of civil law and public law elements (Jagnjić, 2017, 12). Dunković $(2016,8)$ clarifies the specifics of the EU: "EU economic policy has accepted the social market economy (German: "Soziale Marktwirtschaft") according to German model, which represents a concept in between the laissez-faire and the planned economy. The European social model of the market economy is expected to protect the freedom of all supply and demand participants, creating a high level of security for both parties. The main determinants of the model are fairness, social dialogue and the protection of social interests, including the government's responsibility in establishing and maintaining a regulatory framework that will foster competitiveness." By the end of 1973, the European signatory countries of the Treaty of Rome passed the European Charter on Consumer Information Policy and Protection with the consumer rights program, which includes rights to economic interests protection, the right to legal protection and state support, the right to protection of life, health and property when acquiring products and services on the market, the right to information and education of consumers and the right to associate with the purpose of protecting their interests, the right to representation in bodies deciding on matters of their interest (Odabrane, 2004, 19).

In the European Union, the consumer protection development path begins with the 1975 Council Resolution on the Preliminary Programme of the European Economic Community for a Consumer Protection and Information Policy, which for the first time established and enumerated basic consumer rights in the old continent, up to the so-called Lisbon Treaty, namely Art. 12 and Art. 169 of the Treaty on the Functioning of the European Union, which is considered today's constitutional basis for consumer protection (Baretić, 2015, 9).

As of March 15, 1983 and the decision of the United Nations General Assembly, the whole world celebrates the March 15 as a special day of consumer rights adding to this four more rights: the right to meet the basic needs, the right to compensation, the right 
to education and the right to a healthy environment. However, the United Nations General Assembly will make the greatest step in this area by adopting the 1985 Resolution No. $39 / 248$, which largely governs the consumer protection sector, develops consumer information and education institutions, and starts to protect the consumer rights more efficiently. The General Assembly gives guidelines to United Nations members in the form of a suggestion to adopt their own consumer protection laws (Taboroši, 2006, 333). On October 29, 2001, the Republic of Croatia signed the Stabilization and Association Agreement ${ }^{16}$ with the European Community and its member states, undoubtedly deciding to encourage and strengthen the civil sector and further democratize the society by building the institutions of that social segment. Pursuant to Article 69, Paragraph 2 of this Agreement, early alignment should focus on the core parts of the Community acquis relating to the internal market, including, among others, consumer protection. Article 74 of that Agreement defines that the signatory countries undertake to cooperate in the harmonization of consumer protection standards in accordance with standards achieved in the European Community. The Republic of Croatia has taken on the task of harmonizing its legislation and adapting consumer protection in our country to the one that is in effect in the member states, including greater consumer awareness and development of independent organizations, effective legal consumer protection with the aim of increasing the quality of products and services (Mišćenić, 2013, 146, Odabrane, 2004: 19). Consumer protection in the EU member states, including the Republic of Croatia, is regulated by laws, most often (semi)coercive in nature, mainly aimed at protecting the weaker market party, that is the consumer (Baretić, 2015, 8). Consumer protection is an indirect policy of the European Union with shared competence between Union bodies and member states. Harmonization of rules in this area seeks to raise the level of protection of health and safety and economic interests of consumers in all member states, and the harmonization of member states' rights is carried out mainly through directives. Around one hundred directives directly regulate consumer protection area, but through horizontal policy, the number of directives is much higher. We cannot speak of a single European law in the European area, but of Europeanized law, since the directives are not directly applicable but get implemented by each member state in its own legal system (Baretić, 2015, 9). It is worth mentioning the Regulation (EC) no. 2006/2004 of the European Parliament and the Council from 27 October 2004 on cooperation between national authorities responsible for the

${ }^{16}$ Stabilization and Association Agreement signed between the Republic of Croatia and European Committee and its member states (The Act on Confirmation of the Stabilization and Association Agreement between the Republic of Croatia and European Committee and its member states, NN-MU 014/2001). 
enforcement of consumer protection laws (The Regulation of Consumer Protection Cooperation). In addition to directives, consumer acquis also includes regulations and resolutions. EU legal acts specifically regulate the following: protection of consumer health and safety, effective legal consumer protection and protection of consumer economic interests (Baretić, 2015, 9), which includes, among others, the establishment of consumer protection advisory centres. The Ministry of Economy, Entrepreneurship and Crafts in cooperation with consumer protection associations conducted the Consumer Advising project, started in 2008. Advisory centres were located in four regional points (Zagreb, Osijek, Pula, Split). The Ministry of Economy, Entrepreneurship and Crafts commissioned public opinion polls from the Agency for Market Research, Media and Public Opinion, related to how many citizens, when faced with consumer problems, contact a consumer protection association. The research was conducted in September 2018 on the territory of the Republic of Croatia on a sample of 1000 persons over the age of 16 . The research results showed that only $4 \%$ of citizens for their consumer problems address consumer protection associations (Public Contest, 2019).

The aim of this paper is to examine the efficiency and effectiveness of the recent regional network of advisory centres in the implementation of the assigned tasks to protect the rights of consumers - natural persons, i.e. the entire population of the Republic of Croatia. The purpose of the paper is to gain an insight into the functioning of the recent regional network of consumer protection advisory centres in the Republic of Croatia, to identify possible deficiencies and to offer an effective way of their functioning and financing in order to realize their legally assigned role of protecting natural persons as consumers, thereby contributing to the creation of the necessary preconditions for their equal market competition with business entities.

\section{THE CONSUMER PROTECTION SYSTEM IN THE REPUBLIC OF CROATIA}

The aims, measures, priority areas and activities in implementing the consumer protection policy for a four-year period are defined by the National Consumer Protection Program. It is passed by the legislative body of the Republic of Croatia - the Croatian Parliament on the proposal of the Government of the Republic of Croatia, which is obliged to report on the measures taken from that document (Consumer Protection Act, Article 130). Nominal carriers of consumer protection in the Republic of Croatia are the Croatian Parliament, the Government of the Republic of Croatia, the Ministry of the Economy, Entrepreneurship and Crafts, the National Consumer Protection Council, the competent inspectorates and other supervisory bodies, the bodies of local and regional 
self-government units, the Croatian Chamber of Commerce, the Croatian Chamber of Trades and Crafts, the Croatian Employers' Association and the consumer protection associations (National Consumer Protection Program for the period 2013 - 2016; Consumer Protection Act, Article 124). While the National Consumer Protection Program for the period 2013 - 2016 and the National Consumer Protection Program for the period 2017 - 2010 explicitly state that the units of the regional self-government are also the carriers of the consumer protection policy, in the Consumer Protection Act they are not specifically mentioned, but "also other bodies of public authority, each within their jurisdiction" (Consumer Protection Act, Article 124) are included with the units of local self-government. In the earlier strategic documents among the carriers was the President of the Republic of Croatia. It is certainly important to mention the important role of the Ministry of Agriculture when it comes to food quality and safety.

In addition to these nominal carriers, consumers in the Republic of Croatia can seek help at the European Consumer Centre Croatia, which is an integral part of the European Consumer Centre Network (ECC-Net), whose task is to provide advice and enable information on cross-border shopping as well as to assist consumers in cooperation with other European Consumer Centres in dealing with cross-border complaints and disputes (ecc-croatia.hr). They can also seek justice through alternative dispute resolution at consumer conciliation centres at the Croatian Chamber of Commerce, the Croatian Chamber of Trades and Crafts, the Mediation Centre at the Croatian Insurance Bureau, the Mediation Centre "Medijator" Bjelovar, the Mediation Centre at the Croatian Mediation Association, the Mediation Centre at the Croatian Employers' Association and at the Court of Honour at the Croatian Chamber of Commerce and at the Court of Honour of the Croatian Chamber of Trades and Crafts (Alternative Dispute Resolution for Consumers in the Republic of Croatia, 2017, 2). A trader providing public services is required to establish a consumer complaints commission, involving a representative of the Consumer Protection Association (Consumer Protection Act, Article 25, Paragraph 5). Consumers may also seek satisfaction in the regular courts of the Republic of Croatia, bearing in mind that judicial or extrajudicial proceedings can be instituted only after the legal complaint has been delivered in writing to the public service provider and complaints filed with the consumer complaints commission established by the public service provider or after carrying out the procedure established by the law governing the general administrative procedure with regard to protection against the conduct of public service providers (Consumer Protection Act, Article 25a, Paragraph 3).

Consumer protection associations can carry out the following activities: preventively inform and advise consumers on their rights and obligations; conduct a comparative testing of products and a subsequent testing of the products placed on the market in accredited laboratories at home and abroad, and publish results in the media; 
assist the injured consumer in contact with the seller; actively participate in the adoption of legal solutions in the area of consumer protection and carry out other consumer protection activities (Consumer Protection Act, Article 129). From the description of the activities it is evident that along with the Ministry of Economy, Entrepreneurship and Crafts consumer protection organizations carry out a significant part of activities in the area of consumer education, informing and advising (National Consumer Protection Program for the period 2017 - 2020). The activities of all consumer protection carriers defined in the National Consumer Protection Program are coordinated by the Ministry of the Economy, Entrepreneurship and Crafts (Consumer Protection Act, Article 131). As of 2008, this Ministry, in cooperation with consumer protection associations, conducted the Consumer Advising project. They divided the Croatian territory into four regions (Zagreb, Osijek, Rijeka and Dalmatia), according to the criteria familiar only to them. Within the framework of the project, the regional advisory centres in Zagreb, Osijek, Split and Pula were financed, with nine regular employees and a large number of associates for certain areas. Consumers were invited to make calls to a common phone number 072/414414 and to get expert advice from advisors (National Consumer Protection Program for the period $2017-2020)$.

The research hypothesis is that four regional advisory centres cannot adequately address consumer problems of all residents of the Republic of Croatia.

\section{RESEARCH COURSE}

In order to be able to confirm the effectiveness of the past regional organization of consumer protection advisory centres in the Republic of Croatia, a field research was conducted among active consumer protection associations in the Republic of Croatia. The aim of the research is to determine the ability of the recent regional network of consumer protection advisory centres to protect the interests of economically weaker parties, i.e. consumers - natural persons in business transactions on the market. Research tasks were to recognize the views of consumer protection associations in the Republic of Croatia on the effectiveness of the recent regional network of advisory centres, to identify the problems that advisors in associations encounter in providing services in direct and indirect contact with consumers, to identify their view on the optimal number of advisory centres and to offer an effective way for their functioning and financing.

\subsection{Research participants and period}

The research was conducted during the year of 2017. On-line questionnaires were sent to the email addresses of active consumer protection associations from different 
parts of the Republic of Croatia. The completed surveys were collected in a joint link. The questionnaires were completed by eleven associations or relevant respondents, which is extremely high response rate given that other listed associations are mostly formal and in reality inactive.

\subsection{Research material}

To examine the views of consumer protection associations, the authors of this paper prepared online questionnaires, which were sent to respondents on their e-mails, as already mentioned. As a research instrument, five closed type questions and five open type questions were employed. When answering six questions, respondents were asked to give an additional explanation of their responses. The first question was to examine the efficiency of the recent regional organization (network) of four professional advisory centres to meet all the needs for a quality consumer advising in the Republic of Croatia. In the second question the respondents were asked whether one of the four professional advisory centres was headquartered in their city. The third question referred to respondents' opinion on whether eight advisory centres, that is twice as many as the recent ones, even with a smaller number of advisors, would improve the efficiency of the system. In the fourth question the respondents were asked to suggest the cities in which new advisory centres should be located. The following open type question offered the possibility to propose a number of necessary centres in the Republic of Croatia. In the sixth question the respondents had to write whether communication via telephone and email can effectively solve all the problems they face in their daily work with consumers. The seventh question concerned the financing of consumer protection advisory centres. Respondents were asked to provide sources from which the centres should be funded. In the eighth question the respondents were asked about the necessary number of professional advisors in one advisory centre. In the ninth question we asked for the opinion on whether advisors working at consumer protection advisory centres should have a university degree or have a years-long experience of volunteer consumer advising in the association. The tenth question referred to the respondents' view on the work organization in the advisory centres for consumer rights protection, where respondents were asked to list daily and periodic advisory activities. The eleventh question referred to collecting data on consumer problems and distributing them among the past advisory centres and consumer associations. 


\section{RESULTS ANALYSIS}

The processed respondents' answers with brief comments are presented here. The research was carried out in order to gain a clearer image of the capability of the recent regional network of consumer protection advisory centres to meet the consumer needs. The first question related to respondents' opinion on whether the recent regional organization (network) of 4 professional advisory centres (Zagreb, Split, Osijek, Pula phone 072414414 ) is sufficiently efficient to meet all the needs for a quality consumer advising in the Republic of Croatia. Figure 1 gives a graphical representation of respondents' answers.

Figure 1. The views of the associations on the efficiency of the recent regional organization of advisory centres

\section{Is the current regional organization of advisory centers efficient?}

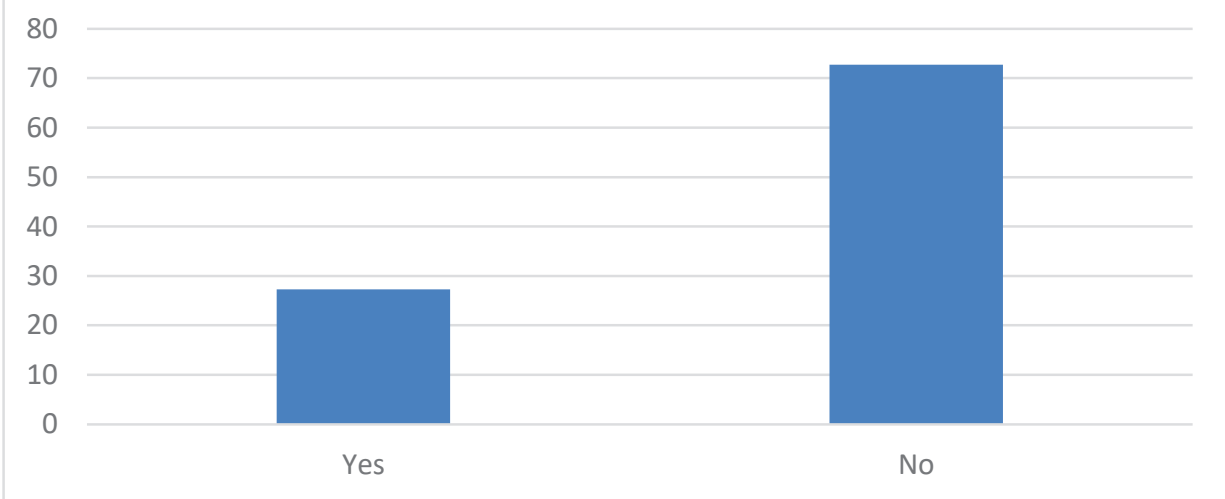

As can be seen from the graph in Figure 1, only $27.27 \%$ of respondents believe that the recent regional organization (network) of 4 professional advisory centres is efficient enough to serve our customers providing a quality consumer advice to them, while $72.73 \%$ believe that such a network cannot adequately respond to such a demanding task. The next question was aimed at finding out if one of the four professional advisory centres was headquartered in the city where respondents worked. From the answer to this question it is obvious that the associations that were satisfied with the Croatian recent network organization covering four advisory centres, with the exception of one, were those which were also carriers of one of the four advisory centres and were financed by the Ministry of Economy, Entrepreneurship and Crafts within the project Consumer 
Advising. Representatives of these associations point out as the benefits of the recent regional organization that experts in the centres daily work on consumer complaints throughout their working hours, thus on a yearly basis resolving tens of thousands of consumer queries. They believe that such organization of advisory centres is quite sufficient in the time of electronic communications. They believe that consumers are also systematically educated while being advised on a specific issue and consumers address the advisors again with confidence also in the case of future disputes with traders. Advisory centres receive lots of feedback on a daily basis from customers who, thanks to the advice of their legal advisors, successfully solved their disputes - out of court, free of charge and quickly, which is most important to citizens. It is pointed out that, in addition to personal advising, advisory staff holds lectures in primary and secondary schools, universities and other institutions, some of which include traders and service providers, they carry out targeted campaigns, projects, seminars and workshops. At the same time, legal advisors in the centres are continuously educated, trained and educated to be more competent in dealing with consumers' disputes with traders. However, when reading the Article 129 of the Consumer Protection Act (OG $41 / 14,110 / 15,14 / 19)$ and the statutes of most consumer protection associations where the scope of their activity is described, it can be easily found that holding preventive informative lectures on consumer rights and duties as well as educating traders, advising consumers, conducting targeted campaigns, planning and carrying out projects, workshops and constant training of the members to increase their knowledge of consumer protection issues, are the usual activities of all consumer protection associations whether they are financed by the Ministry of Economics, Entrepreneurship and Crafts within the project Consumer advising or not.

Precisely the representatives of the associations who mostly assessed the recent regional organization (network) of the four professional advisory centres as not being efficient enough highlight the shortcomings thereof in the explanation of their responses. It is pointed out how these four centres simply cannot physically handle activities related the 4500000 consumers in the Republic of Croatia. The main disadvantage is the lack of professional advisors compared to the number of consumers' inquiries and their inaccessibility to consumers, i.e. the excessive physical distance from the consumers they provide their services to. They illustrated this with rhetorical questions such as "How will consumers from Dubrovnik or Gospić come to an advisory centre in Split or Pula?" which are geographically closest to them. In that context, Article 126 of the Consumer Protection Act is highlighted, obliging all local self-government units to organize, among other things, consumer advising, which in other words means the existence of advisory centres of this type. They are obliged to support the centres and provide them with a working area. They therefore believe the four existing centres do not 
at all have a basis in the Consumer Protection Act, but have been invented by the Ministry of Economy, Entrepreneurship and Crafts, or some of its employees related to the regional division of Croatia, whereupon the four associations have been chosen to be the advisory carriers in a privileged position to all other consumer protection associations in the Republic of Croatia. Respondents do not support the allocation of budget grants amounting to HRK $300-400$ thousand to each of these four associations, while others do not receive anything. Some will point out that the organization and team work of advisory centres is extremely important. This means the need for more 'resources', i.e. areas of consumer protection to be addressed by individual centres, as well as the need for a larger number of competent expert advisors. They think that the advisory centres' working time should be prolonged in order to help the injured consumer to establish contact in an easier way and to get help faster, which would be more concrete and effective. This does not necessarily mean that all advisors should have to sit and wait in one place, but certain regional advisory centres could specialize for certain areas of consumer protection, which would then justify their higher number. Most respondents think that a larger number of advisory centres are needed, with the good coordination of all associations from this area.

The arguments of most respondents mentioned here are confirmed by the Ministry of Economy, Entrepreneurship and Crafts of the Republic of Croatia in the National Consumer Protection Program for the period 2017 - 2020, in which it explicitly states that according to the Consumer Conditions Scoreboard in 2015, the Republic of Croatia has a very low consumer confidence index, meaning that the system of information, education and the efficiency of solving specific consumer problems does not function at a satisfactory level. This is also confirmed in the statement of the Minister of Economy on the occasion of marking the World Consumer Rights Day in 2018 when she said that the possibility of introducing two more advisory centres for consumers in the Republic of Croatia is being considered. In the meantime, the centres were established. The next question related to the opinion of the associations whether the doubling of the number of the recent advisory centres would improve the efficiency of the consumer protection system in the Republic of Croatia, i.e. eight of them even with a smaller number of employees. The results are shown in the Figure 2. 
Figure 2. The views of associations related to doubling the number of advisory centres

Would doubling the number of the advisory centers significantly improve the consumer protection system?

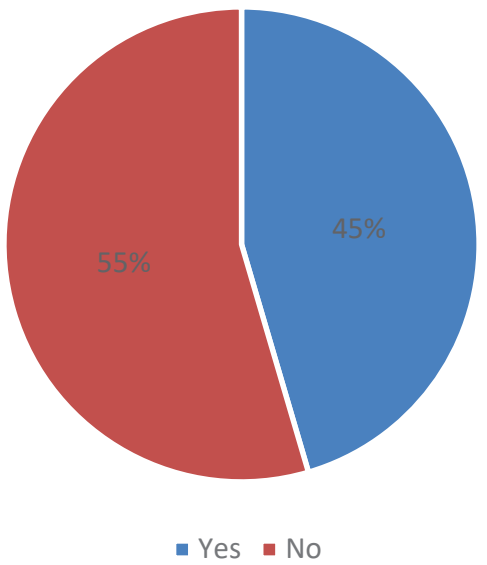

As can be seen from the graph, the opinions of the respondents are quite divided. A little less than half of the respondents (45\%) believe that doubling the number of the centres would significantly improve the system, while $55 \%$ do not share that opinion. Those who consider the extension to the eight centres to be a good solution, along with the recent four centres, suggest their opening in the following cities: Rijeka, Varaždin, Zadar, Vinkovci, Karlovac, Požega, Dubrovnik, Kutina. In their suggestions, the respondents obviously held on to the geographical location of their associations and the headquarters of certain counties in which consumer protection organizations are active, as some of them mentioned. They point out that it is necessary to make an analysis to determine towards which areas the inhabitants of particular regions gravitate, i.e. where the institutions are located, and to enable the work of advisors there. Some pointed out that one advisor can cover two counties, working three days in one, and possibly two days in the other, neighbouring county.

Respondents were also given the opportunity to submit their proposal regarding the required number of professional advisory centres in the Republic of Croatia. The answers were varied. The recent four advisory centres were proposed again by those associations which until recently participated in the Consumer Advising project, i.e. within which a professional advisory centre operated with the support of the Ministry of Economy, Entrepreneurship and Crafts. They added that they certainly need to be institutionalized in some way, that is, the state should take much more serious account of 
their funding. Some will agree with the offered number of eight advisory centres, but emphasize that this would be the minimum number. Most respondents believe there should be more. Some will suggest eight to ten, some twelve. Some will again rely on the legal framework of the Republic of Croatia, which states that ALL units of local selfgovernment should have advisory centres. They have understanding for some smaller municipalities which will not be able to realize this, but they argue that changes to the Consumer Protection Act should be considered to define mandatory organization of consumer protection advisory centres at least in larger local self-government units (e.g. more than 30000 people). As a significant lack of current advisory network the respondents have already stressed the excessive dislocation from the people they need to provide advisory services to. It is necessary to find out whether activists of the association, doing their job on a daily basis, can via phone and email efficiently solve all the consumer problems they encounter in their daily work with consumers. Figure 3 shows a graphical representation of respondents' answers.

Figure 3. The views of associations related to resolving consumer problems remotely

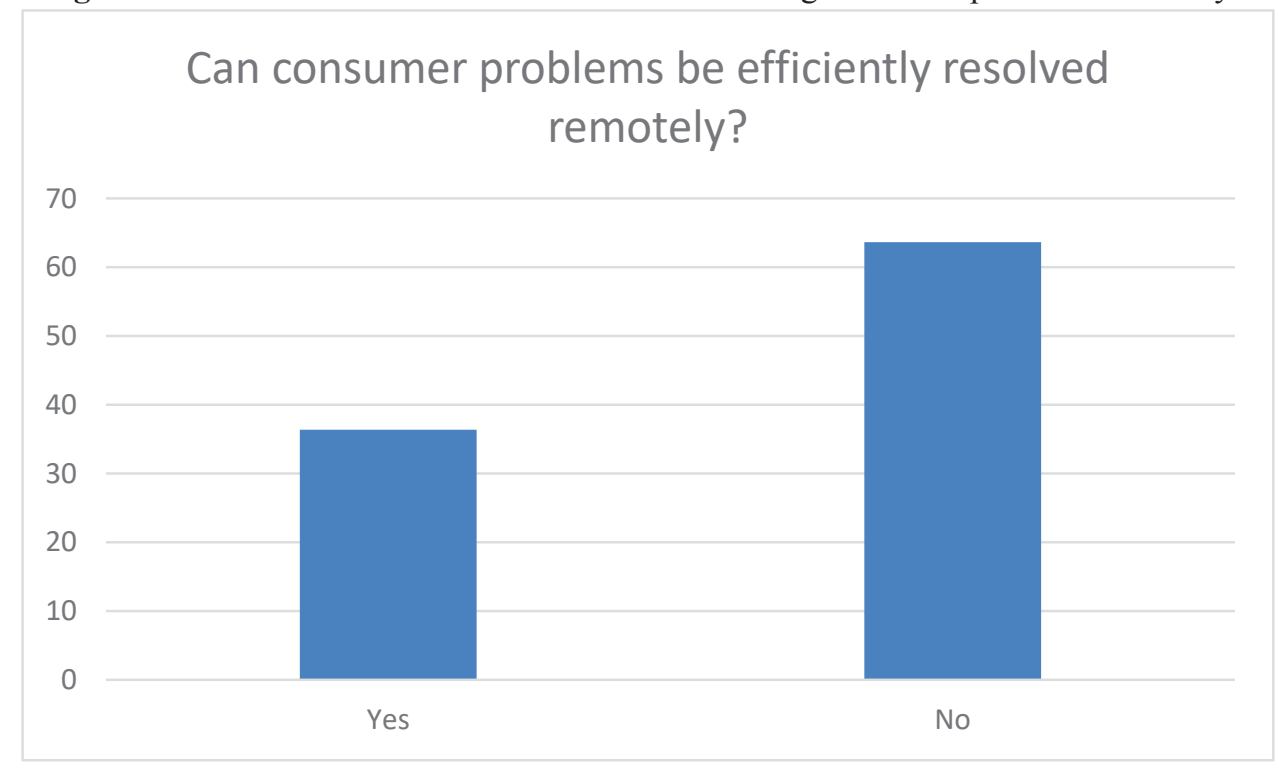

From the graph in Figure 3, it is obvious that remotely, via phone and e-mail, not all the consumer problems encountered by advisors in associations can be efficiently resolved. This opinion is shared by $63.64 \%$ of respondents, while somewhat more than one third $(36.36 \%)$ believes to be able to efficiently solve all consumer problems. Advocates of remote problem solving either fail to explain anything or point 
out that it is a quick, easy and timely problem solving. Most who think that this cannot solve all the problems give a much more extensive explanation. They find that telephone and e-mail communication can effectively address minor problems, especially when it comes to correspondence with consumers who are computer-literate and can write a complaint by themselves. Those are mostly younger and more educated people. However, they think there are too few computer-literate citizens in our country as well as those who understand the legal problems they are facing. There is often a need for personal contact with the consumer to get an insight into the correspondence received by consumers (bills, warnings, distrains and the like) which they had with the traders, as well as all the details of complaint, in order to identify a specific problem. This is especially important in more complex cases, for better explanation of problems, insights into more extensive documentation, arrangements for taking further steps, etc. They particularly emphasize the problem of older consumers, most often retired people, who are mostly not using email, and can hardly explain the problem through the phone. They believe that the associations and thus the advisory centres should pay particular attention precisely to them. They are often defrauded by phone so it is hard to expect that they will solve their problem in this way. Personal contact with the consumer is particularly needed in the case of a more general consumer education about their rights and obligations, aiming to prevent the future disputes that consumers may face. In this way, consumers also gain greater confidence in the legal advisors and occasionally listen and apply their advice. It is stated that telephone conversation should not be too long, as it causes the loss of communication efficiency.

The research was further aimed at finding out the views of the respondents as to who should finance these advisory centres. 
Figure 4. The views of associations related to sources of financing the advisory centres

\section{Sources of financing the advisory centers}

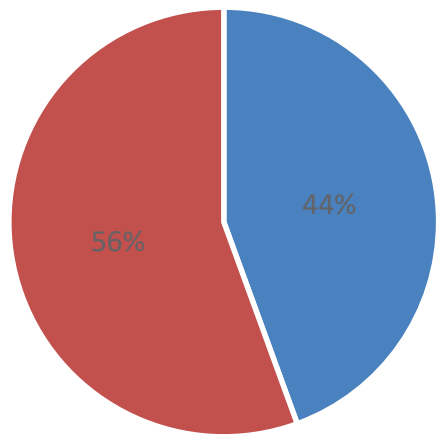

- Ministry of Economy

- Ministry of Economy + local and regional self-goverment units

As can be seen in Graph 4, 44\% of respondents believe that advisory centre should be financed from the state budget, i.e. by the Ministry of Economy, Entrepreneurship and Crafts as previous four centres. There is somewhat larger number of those who want to include local and regional self-government units (56\%) along with the state budget for the funding of the centre, adding the one of the respondents who says that the costs should also be borne by traders who are, compared to consumers, economically stronger party of the market. Another respondent suggests that along with the funds from the Ministry of Economy, Entrepreneurship and Crafts of the Republic of Croatia and the local self-government units, the money for the centre should be obtained through paying membership fees, probably similar to the Franak association, wherein advising is conditioned by membership and paying a membership fee. It should be noted that exceptionally rare are the consumer protection associations in the Republic of Croatia which conduct such a business policy, although it is not uncommon for people to join the associations when they have a problem thinking they will avoid paying and get free advice. In their comment on this issue the respondents even highlighted that the work of the past advisory centres was very effective, popular and useful, precisely because it was free of charge as the consumers could not bear the costs of advising due to the extremely bad financial situation. There were also proposals that cannot be categorized into any of the aforementioned categories as some consumers merely state that future centres should be financed as much as possible from an independent and impartial source $(9.09 \%)$, 
apparently alluding to unequal the distribution of the state money to only four associations in the Republic of Croatia.

As can be seen, more than a third of the respondents believe that the burden of financing the advisory centres should be taken over by local and regional self-government units as well. As previously mentioned, referring to the consumer protection policy carriers in the Republic of Croatia, regional self-government units are explicitly mentioned in national consumer protection programs, while in the Consumer Protection Act they are implicitly mentioned. When it comes to units of local self-government, the thing is clearer. Namely, while Article 129 of the Consumer Protection Act states that "Consumer protection associations can, in the area of consumer protection, carry out especially the following activities" (authors' emphasis), Article 126 states: "Local selfgovernment units are obliged to take measures and activities within their area of competence regarding consumer protection" (authors' emphasis). Thus, associations can carry out certain activities from that area if conditions are met, while local selfgovernment units are obliged to carry out the following measures and activities: "1. to inform and carry out consumer education; 2 . to organize consumer advising, 3 . to initiate and support projects of associations that improve and promote consumer rights, 4 . to participate in the implementation of the National Consumer Protection Program at the local level; 5. to perform other tasks in accordance with special regulations" (Consumer Protection Act, Article 126). From the third mandatory measure of local self-government units it is obvious not only that they must financially support local consumer protection projects, but also initiate them themselves. Advisory centres for consumer protection can certainly, along with the preventive, be counted among the most important projects that associations can implement.

As can be seen from the previous answers, the representatives of the associations believe that a much wider organization (network) of the advisory centres should be formed in the Republic of Croatia than it is today. The next question was aimed at finding out how many professional advisors should work in one of these centres. The respondents were offered the following options: one person working half-time, one person working full-time, two persons working full-time, three persons working full-time and four persons working full-time, that is the way the recent four centres functioned on average. 
Figure 5. The views of associations related to the necessary number of advisors working in advisory centre

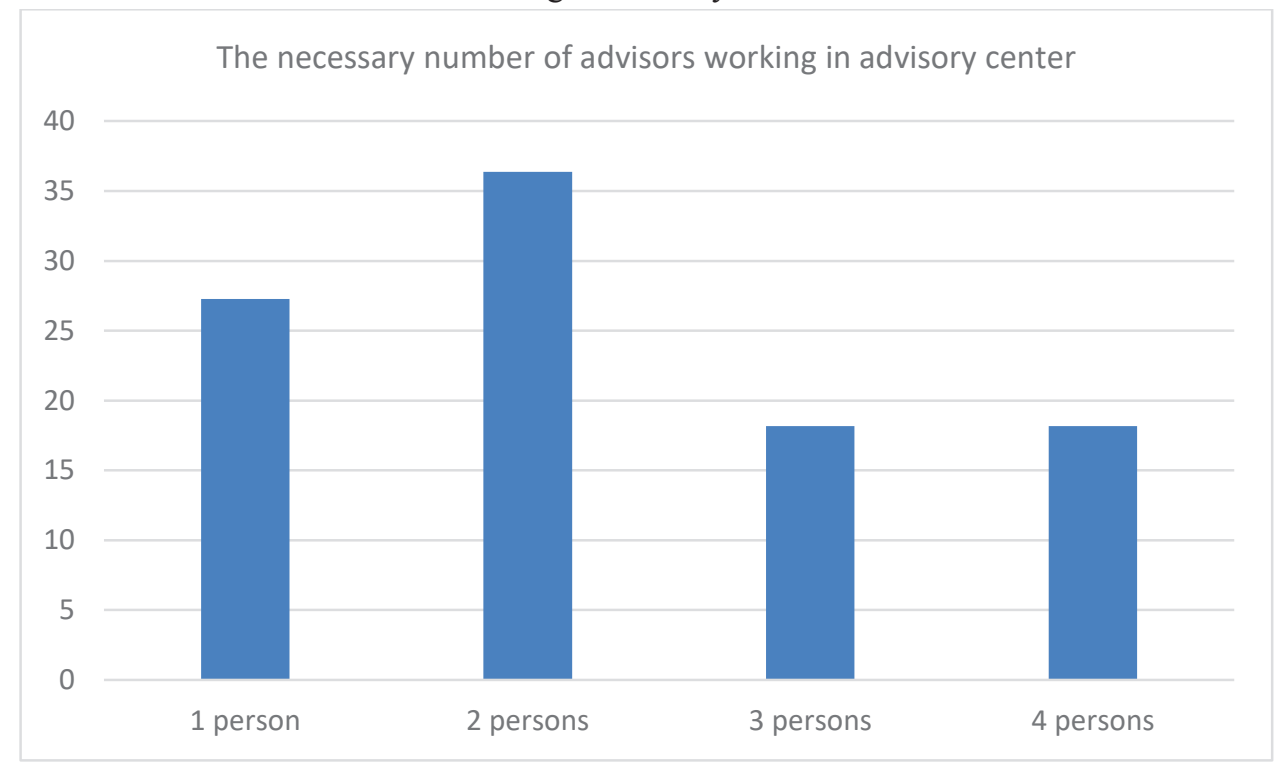

As shown in Graph 5, the largest number of respondents (36.36\%) believe that two full-time employees could successfully perform the job of professional advisors, while $27.27 \%$ think that one person would be enough. Minority estimates that more professionals are needed for this job: three (18.18\%) or four $(18.18 \%)$. There is a good chance that those saying that a smaller number of advisors is enough are right because by increasing the number of advisory centres, the network of the past four would certainly receive less phone calls and emails from other areas, and it would be more useful for consumers to find a closer advisory centre where they can personally present their problem and provide documentation, and the service would be of better quality. Therefore, it can certainly be concluded that for a more efficient functioning of consumer protection system a smaller number of advisors in a larger number of centres/points than in the recent centres is more useful.

Volunteer activists of different educational profiles have been working with consumers in the associations for more than a decade. One of the conditions for an association to apply for a project for the Consumer Advising of the Ministry of Economy, Entrepreneurship and Crafts is, among others, that the association employs a lawyer with a degree. Therefore, the research was further aimed at finding out if the advisors in advisory centres should finish a concrete study program or a years-long experience of volunteering in the association is enough. The representatives of the associations argue 
that university education can certainly not be of harm, especially with regard to studies in law and economy, completed by the majority of the present inspectors working for supervisory agencies. Engineers would also be welcome when it comes to technical issues. However, they point out the practice has shown advisors with other degrees also do well in advisory jobs because practical experience cannot be matched. They believe the quality of conducting an advisory job requires additional education in the area of consumer protection, regardless of the acquired professional qualification, because often many laws change, thus it is necessary to know them. It is also necessary to be familiar with the specific situations and to have communication skills in stressful situations. There is a Regulation on taking the exam for obtaining a license of "the advisor in the consumer protection advisory centres". Without having passed the exam, no one should be employed at the advisory centre, because no degree or volunteer experience is a guarantee of a "quality advisor". Only the successfully passed exam confirms the competences for providing quality advice to consumers.

Furthermore, respondents had to express their opinion on how the work of the consumer protection advisory centre should be organized and were asked what should be included in their daily and periodic activities. Most of them believe the centres should work full-time each working day, be institutionalized, employ advisors and, if necessary, use the help of volunteer advisors who would also be paid for this work through an employment contract. They think that the work of the advisory centre should include the following activities: clarification of the rules and procedures for exercising rights and economic interests of consumers, assistance in solving specific consumer inquiries related to the violation of their rights by traders, mediation in solving problems arising between consumers and traders on consumer's demand, input of information regarding consumer inquiries into the Central Consumer Protection Information System, co-operation with other advisory centres and the competent Ministry of Economy, Entrepreneurship and Crafts of the Republic of Croatia, lectures organized for citizens, seminars, campaigns raising awareness of individuals and consumer groups, as well as various educations organized for advisors.

In their response to the last question, respondents had to state whether the collecting data on consumer problems and solving and distributing them in the current centres is well organized. Those in favour of it will support this by conducting detailed records of each consumer complaint and forwarding it to the Ministry of Economy, Entrepreneurship and Crafts of the Republic of Croatia, as well as keeping track of the positive feedback received by the advisory centres from the consumers who successfully solved their disputes. Statistical records are also produced from these records, which are a good indicator of major consumer problems in the Republic of Croatia, as well as for the customers of the most problematic traders and service providers. Most respondents, 
yet, are not satisfied with the current model. They criticize the fact that feedback on successful dispute resolution has never been published so that consumers and consumer associations can use it. Association representatives deny knowing anything about the existence of significant exchanges of information between the existing centres and other consumer rights protection organizations with regard to consumer complaints. What is more, some respondents point out that not many people in our country know how many consumer rights protection associations exists in the field and which ones are still active, and this is not particularly well known to the competent Ministry of Economy, Entrepreneurship and Crafts of the Republic of Croatia either. This statement can be confirmed if we take a look at the website of the competent Ministry, where there is no information about the associations, while a few years ago there was a list of active associations. However, this is not the only critique addressing the competent Ministry. Respondents notice there is little data provided by the European Consumer Centre. The data should be available in several world languages, for foreign tourists, who are also consumers. Respondents believe that each local self-government unit and each consumer rights protection association should submit an annual report on the state of consumer protection in its area, as this is the only way to determine the actual situation in accordance with Eurobarometer surveys, compared to the present situation, where we occupy the 28th place in the European Union, mostly because the survey is not carried out in non-member countries. Otherwise we would be even lower ranked in Europe, while the Ministry at the same time shows off with significant achievements. Respondents say different cases and especially their solutions should be exchanged with all the organizations dealing with this issue in order to educate other volunteers in the consumer movement in the Republic of Croatia. To this end, they propose to make a base containing consumer questions and answers available to all advisory centres to help them answer the questions in a unique way. This would make it easier to spot problems that arise in a particular area and to solve them jointly. Since the present advisory centres are better equipped with staff and technical equipment, more competent with regard to the level of expertise and experience, and incomparably better funded than other consumer protection associations, it is believed that advisors from the centres should be more systematically engaged in the work for other associations as well. The centers should be connected with other associations in their area of activity in order to collect data from the field, to process them and provide feedback for these associations. Information important for all consumers should be launched both in national and all local media in a coordinate way, so that consumers are timely informed about changes in the area. Consumers are eager to receive accurate information that will serve them in making market decisions. More than a third of Europeans feel inadequately informed as consumers, while at the same time the need of an average consumer for information is growing (Dunković, 2016, 31). Based on 
the collected and processed information, the system of consumer protection should be continuously developed and upgraded.

\section{CONCLUSION}

The research results confirm the set hypothesis that four regional advisory centres cannot adequately address consumer problems of all residents of the Republic of Croatia. Almost $73 \%$ of respondents believe that the past organization of the centres is insufficient. This is also confirmed by the aforementioned survey of the Ministry of Economy, Entrepreneurship and Crafts, which shows that only $4 \%$ of the population of the Republic of Croatia asked the consumer associations for help, therefore as from January 1, 2019, before the expiry of the deadline, the Ministry terminated the project Consumer Advising, that is the network of four past advisory centres. With regards to the results of the mentioned research, the elimination of the inefficient regional organization of the Advisory Centres is completely justified. The Ministry emphasizes the need for strengthening of all consumer protection associations in order to increase their visibility through the intensification of promotional activities and the procurement of new information and communication equipment (Public Contest, 2019). This has clearly shown that this network does not meet the set task and that it has to involve a much larger number of associations in the Republic of Croatia. The National Consumer Protection Program for the period 2017 - 2020 also emphasizes the need for a more intensive cooperation with "well-structured consumer protection associations in the field of consumer advising, informing and education" thus "contributing significantly to a higher level of consumer information as well as to sensitizing the public regarding this issue" (National Consumer Protection Program for the period 2017 - 2020).

Increasing the number of advisory centres would reduce the other key shortcomings of the past organization (network), i.e. the excessive physical distance from the consumers to whom they provide the service, as the past four centres would have less job to do and people would be redirected to the nearest centres, thereby gaining a better quality service because they could communicate directly with advisors. This is often crucial for a good problem solving due to the complexity of a particular case or the amount of documentation. Most respondents believe that the majority of consumer problems $(63.34 \%)$ cannot be remotely resolved by phone or e-mail. The system would function much more efficiently to the satisfaction of consumers, i.e. all citizens of the Republic of Croatia, if the concentration of four advisors in a single regional centre would be more rationally distributed to a much larger number of centres with a smaller number of advisors. This is especially important for older people who mostly use poorly the 
information technology, are unable to pass on the exact details of their case through the phone because they cannot cope with a complex correspondence with the trader. They are often defrauded over the phone and are less likely to be able to solve their problem in this way. Other vulnerable groups of the population, especially those with poor financial situation often located in rural areas, would be more protected because they would not have to spend money to go to remote cities where consumer advisory centres were situated until recently. Therefore, it can certainly be concluded that for a more efficient functioning of consumer protection system a smaller number of advisors in a larger number of centres/points than in the recent centres is more useful.

Advisory centres should hire a certain number of advisors depending on the size of the population they provide services for, hiring also professionals and, where appropriate, volunteers through the employment contract. The centres should be institutionalized, and all advisors who provide services should have a license and be constantly educated because of the large number of laws that they need to be familiar with and which change in our country too quickly. Additionally, advisors need to be timely acquainted with the implementation of European legislation, such as the implementing Regulation of the EU Commission on how to use the online dispute resolution platform, and the like, as well as any potential complications that may arise in solving the dispute due to the improper implementation of the Directive in certain national legislations of EU member states (Mišćenić, Butorac Malnar, 2017, 103, 137). In order for the consumer protection system to function more efficiently and in a quality way, the Ministry of the Economy, Entrepreneurship and Crafts of the Republic of Croatia must ensure the implementation of the Consumer Protection Act, in particular the implementation of Article 126, which obliges all local self-government units to take measures and activities within their area of consumer protection, which includes, among other things, the organization of consumer advising, which would certainly create the prerequisites for a better functioning of consumer protection associations and the opening of new advisory centres. The local self-government units certainly must take over their part of responsibility and together with local consumer protection associations and with regional self-government units try to form advisory centre for consumers in at least one county centre, and if possible in every bigger county point. The potential centres should connect to other consumer rights protection associations to collect the field data, process them, and provide feedback to these associations. Exchanging experience on specific cases would enable the advisors a much faster improvement in their work. Based on the collected and processed information, the consumer rights protection system should be constantly developed and upgraded. 


\section{REFERENCES:}

1. Alternativno rješavanje potrošačkih sporova u Republici Hrvatskoj (September 2017). Zagreb: Ministarstvo gospodarstva, poduzetništva i obrta Republike Hrvatske.

2. Baretić, M. (2015). Zaštita potrošača: minivodič za poslovnu zajednicu. Ministarstvo gospodarstva Republike Hrvatske.

3. Dunković, D. (2016). Zaštita potrošača i poslovno upravljanje. Zagreb: Ekonomski Fakultet Sveučilišta u Zagrebu.

4. Europski potrošački centar Republika Hrvatska. Available at: http://ecccroatia.hr/ (Accessed: 3. 3. 2019).

5. Jagnić, L. (2017). Zaštita potrošača u Republici Hrvatskoj. Final thesis. Split: Ekonomski fakultet Sveučilišta u Splitu.

6. Kesić, T. (2006). Ponašanje potrošača. Zagreb: Opinio.

7. Klarić P., Vedriš M. (2009). Građansko pravo. Zagreb: Narodne novine.

8. Mintas Hodak, Lj. (2010). Osnove trgovačkog prava. Zagreb: Mate.

9. Mišćenić, E. (2013). Usklađivanje prava zaštite potrošača u Republici Hrvatskoj. Godišnjak Akademije pravnih znanosti Hrvatske, 4 (1), pp. 145-176.

10. Mišćenić, E., Butorac Malnar, V. (2017). Online rješavanje potrošačkih sporova. Godišnjak Akademije pravnih znanosti Hrvatske, 3 (1), pp. 103-142.

11. Nacionalni program zaštite potrošača za razdoblje od 2013. do 2016. godine. official gazette Narodne novine 90/2013.

12. Nacionalni program zaštite potrošača za razdoblje od 2017. do 2020. godine, official gazette Narodne novine 20/2018.

13. Odabrane stranice: Zaštita potrošača - Zakon o zaštiti potrošača, (2004) Meso, Vol. 6, br. 2, pp. 19.

14. Taboroši, S. (2006). Ekonomsko pravo, drugo izmjenjeno i dopunjeno izdanje. Beograd: Centar za publikacije Pravnog fakulteta Univerziteta u Beogradu.

15. The Act on Confirmation of the Stabilization and Association Agreement between the European Communities and their Member States NN-MU 014/2001.

16. Consumer Protection Act. official gazette Narodne novine 41/14, 110/15, 14/19.

17. Javni natječaj za dodjelu financijske podrške projektima udruga koje djeluju u području zaštite prava potrošača u 2019. godini. (21. 12. 2018)

//www.mingo.hr/page/javni-natjecaj-za-dodjelu-financijske-podrskeprojektima-udruga-koje-djeluju-u-podrucju-zastite-prava-potrosaca-u-2019godini-1 (Accessed: 8. 3. 2019)

18. 15 U. S. Code, Chapter 41 of The Consumer Credit Protection Act https://uscode.house.gov/view.xhtml?path=/prelim@title15/chapter41\&edition $=$ prelim (8. 12. 2019.) 


\title{
UČINKOVITOST REGIONALNE ORGANIZACIJE SAVJETOVALIŠTA ZA ZAŠTITU PRAVA POTROŠAČA U REPUBLICI HRVATSKOJ
}

\author{
Josip Miletić \& Jurica Bosna
}

\section{Sažetak}

$U$ radu se problematizira učinkovitost $i$ održivost donedavne regionalne organizacije savjetovališta za zaštitu prava potrošača u Republici Hrvatskoj u kontekstu opravdanosti njenoga ukidanja od strane Ministarstva gospodarstva, poduzetništva $i$ obrta. Rad uključuje i terensko istraživanje provedeno među aktivnim udrugama za zaštitu potrošača u Republici Hrvatskoj. Nastoji se odrediti sposobnost nekadašnje regionalne mreže savjetovališta za zaštitu prava potrošača u zadovoljavanju potreba najznačajnijega gospodarskoga segmenta - stanovništva Republike Hrvatske, odnosno potrošača - fizičkih osoba, kao preduvjeta za ravnopravnu tržišnu utakmicu s poslovnim subjektima. Analizira se financijska konstrukcija nacionalne, regionalne (područne) $i$ lokalne razine sustava zaštite prava potrošača u Republici Hrvatskoj. Rezultati istraživanja upućuju na nedovoljnu učinkovitost i neodrživost donedavnog modela te se nude alternativna rješenja koja će na učinkovitiji način zadovoljiti potrebe stanovništva svake pojedine hrvatske regije, a time i cjelokupnog stanovništva Republike Hrvatske.

Ključne riječi: potrošači, regionalni ustroj, zaštita prava potrošača, savjetovališta za zaštitu prava potrošača. 